\title{
Tópicos de periodização na história da língua portuguesa
}

\author{
Maria José Carvalho \\ CELGA-ILTEC (Faculdade de Letras da Universidade de Coimbra)
}

Data de recepción: 17/06/2019 | Data de aceptación: 12/11/2019

\begin{abstract}
Resumo:
Pretende-se, neste artigo, esboçar uma proposta de periodização do português antigo, com base em critérios estritamente linguísticos. Fixámos como campo de estudo um corpus notarial seriado cronologicamente (Carvalho 2017a) e analisámos a evolução e o comportamento de vários fenómenos, distribuídos pelos diferentes níveis de análise: fonologia (na sua relação com a codificação gráfica), morfologia, sintaxe, semântica, léxico e discurso. O objetivo foi estabelecer balizas de separação mais ou menos comuns a vários deles, no sentido de tornar mais rigorosas as designações tomadas de empréstimo da história literária e cultural. Depois de delimitadas essas franjas de separação, de menor amplitude do que aquelas que têm sido consideradas pelos periodizadores da língua, apresentar-se-á o termo ad quem dos fenómenos mais representativos do português antigo, manifestados nos textos de uma zona geográfica nevrálgica no processo de estandardização e de fixação da norma: a região Centro-litoral portuguesa.
\end{abstract}

\section{Palavras-chave:}

Linguística Socio-histórica, História da Língua Portuguesa, Periodização linguística, Estandardização.

\section{Sumário:}

1. Periodização da língua portuguesa: status qucestionis 2. Nova proposta de periodização do "Português antigo" 2.1 Português arcaico: 1" fase (Até 1350/1360) 2.2 Português arcaico: $2^{a}$ fase (até c. 1380/1390) 2.3. A "elaboração" da língua portuguesa (1380/13901425/1430) 2.4. Da "elaboração" da língua à estandardização: a transição (1425/1430-1450) 2.5 O Português (pré-) moderno: da codificação normativa aos "dialectalismos” (1450/14601485) 2.6 O Português moderno (1485-...) 3. Conclusões. 


\title{
Schemes for the periodisation of Portuguese linguistic history
}

\begin{abstract}
:
The article outlines a scheme for the periodisation of early Portuguese, on the basis of strictly linguistic criteria. Our study is based on a corpus of chronologically ordered notarial documents (Carvalho 2017a); we analyse the evolution and behaviour of various phenomena, distributed through the different levels of analysis: phonology (as related to graphical codification), morphology, syntax, semantics, lexis and discourse. The aim has been to establish delimiting markers that are broadly common to many of them, in order to make the designations borrowed from literary and cultural history more rigorous. Having outlining these time-zones, which are narrower than those previously considered in periodisations of the language, we present the terminus ad quem of the most representative phenomena of early Portuguese, as shown in texts from a nerve-center of the process of standardisation and fixation of the norm: the Central-coastal region.
\end{abstract}

\section{Key words:}

Socio-historical linguistics, History of Portuguese, Linguistic periodisation, Standardisation.

\section{Contents:}

1. Periodisation of Portuguese: status quæstionis 2. New proposal for periodisation of 'early Portuguese' 2.1 Archaic Portuguese: $1^{\text {st }}$ phase (to 1350/1360) 2.2 Archaic Portuguese: $2^{\text {nd }}$ phase (to c. 1380/1390) 2.3. The "elaboration" of Portuguese (1380/1390-1425/1430) 2.4. From the "elaboration" of Portuguese to standardisation: transition (1425/1430-1450) 2.5 (Pre-)modern Portuguese: from normative codification to "dialectisms" (1450/1460-1485) 2.6 Modern Portuguese (1485-...) 3. Conclusions. 
Uma língua não nasce em dia e hora certa, nem evoluciona num momento de um estado para o outro

(Carolina Michaëlis de Vasconcelos 1956: 19)

\section{Periodização da língua portuguesa: status quaestionis}

É bem conhecido dos historiadores da língua que as designações para as divisões periodológicas praticadas até hoje se baseiam em factos que lhe são externos, normalmente procedentes da história literária e cultural, obliterando muitas vezes as transformações da própria estrutura linguística no seu devir temporal ${ }^{1}$. De facto, a designação "Português arcaico ou antigo" é extremamente abrangente e estendese de 1200 a 1540, de acordo com Leite de Vasconcelos, Carolina Michaëlis de Vasconcelos e Said Ali. Os primeiros autores coincidem na fixação da data de 1350 para a delimitação do período Galego-português (ou Português-galego), também chamado de "trovadoresco" por Carolina Michaëlis de Vasconcelos, apesar de Said Ali considerar que "Português antigo" corresponde a todo o período que se estende até aos últimos anos do século XV ou primeiros anos do século XVI. Baseados eventualmente em critérios literários, Carolina Michaëlis de Vasconcelos e Serafim da Silva Neto preferem identificar um subperíodo entre 1350 (ou entre 1385) e os inícios do século XVI, que designam de "Período da prosa histórica ou nacional"”. Pilar Vásquez Cuesta prolonga um pouco mais os limites cronológicos do "Galego-português", apontando como seu termo ad quem $1385^{3}$, e designando de "Pré-clássico" aquele que se estende desde aí até 1536. Luís Filipe de Lindley Cintra, por seu turno, designa de "Português antigo" todo o período da história da língua portuguesa que se estende até 1420, designando

1 Vejam-se, a título de exemplo, o Quadro I ("Propostas de periodização da História da Língua Portuguesa"), elaborado por Ana Maria Martins (2002: 267), o Quadro 1 ("Propostas para a delimitação do português arcaico"), elaborado por Rosa Virgínia Mattos e Silva (Silva 2008, I: 20) ou ainda o "Quadro-síntese comparativo", elaborado por Brocardo (2014: 105).

2 Serafim da Silva Neto designa essa segunda fase do período arcaico, «a fase da prosa histórica, verdadeira e exclusivamente portuguesa, de 1385 até o século XVI» (Neto 19864: 398), admitindo mais adiante, ao atribuir-lhe a designação de português comum, que se trata do «período que D. Carolina chama da prosa histórica» (Neto 19864: 405).

3 Recordamos as palavras da autora: «En nuestra opinión, sin embargo, resultaría mucho más significativa otra fecha próxima: la de la batalla de Aljubarrota, que tiene lugar en 1385 y por la que Portugal da muestras definitivas de su decisión de construir una nacionalidad independiente dentro de la Península» (Vázquez Cuesta 1971, I, 202). 
de "Português médio" a etapa que se situa entre essa data e meados do século XVI (cf. Castro 1999: 369). Ivo Castro, corroborando esta designação (que tem sido consagrada), considera-a uma faixa de transição para uma "plataforma estável" (Castro 1991: 243, 2006: 149). Evanildo Bechara (1991), por outro lado, considerando apenas fases da língua escrita, distingue duas fases menos extensas: "Português arcaico", até finais do século XIV e "Arcaico médio" (até à primeira metade do século XVI).

Baseada em quatro fenómenos de natureza fonética e morfológica (maioritariamente analisados já por Carvalho 1996), e com base num corpus da primeira metade do século XV, Esperança Cardeira refere uma «transição de fase» entre o português antigo e o português médio, situando-a nessa metade de século (Cardeira 2005: 291). Em 2008, Rosa Virgínia Mattos e Silva apresentou uma série de indicadores de carácter morfossintático e sintático, concluindo que alguns dos factos linguísticos estudados pela sua equipa (PROHPOR) começam a desaparecer em finais do século XIV e outros prolongam-se pelo século XVI (Silva 2008: 21).

A designação de "Português moderno" é atribuída por José Leite de Vasconcelos, Carolina Michaëlis de Vasconcelos e Said Ali ao português que começa nos primeiros anos (ou meados) do século XVI até à atualidade, embora este último autor o subdivida ainda em "quinhentista", "seiscentista", "setecentista" e "hodierno". Já Vázquez Cuesta e Lindley Cintra designam de "Clássico" o período da língua que vai desde o século XVI até ao século XVIII, considerando apenas a partir daqui a fase do português moderno. Evanildo Bechara, por sua vez, prefere designar de "Português moderno" ao português situado entre meados do século XVI e finais do século XVII, reservando a designação de "hodierna" para a fase que se estende desde o início do século XVIII até à atualidade.

\section{Nova proposta de periodização do "Português antigo"}

Assim, depois de analisados variadíssimos fenómenos pertencentes aos diferentes níveis de análise, tentaremos apresentar alguns dados para o estabelecimento das suas cronologias, que possam contribuir para a desagregação dos dois compactos blocos tradicionalmente estabelecidos na história da língua portuguesa - o "Português arcaico" e o "Português moderno" - em épocas mais nitidamente diferenciadas. De facto, parece improcedente continuar a usar esta bipartição, uma vez que ela decalca de perto o binómio 'Idade Média' vs. 'Idade Moderna', que pertence, naturalmente, à história cultural.

Como observa Ivo Castro, 
que a língua não evolui paulatinamente, como um ribeiro de Bernardim (...), sabe-se. Mas (...), não deve surpreender que os momentos que mais apaixonam os linguistas sejam, desde sempre, os de grande aceleração, aqueles em que a língua, ou como grande animal que se remexe no sono, ou como placa tectónica que se acomoda a novas pressões, muda em pouco mais tempo que a vida de um homem o inventário e a correlação das suas unidades constitutivas (Castro 1993: 97-98).

Reconhecendo a dificuldade em delimitar períodos na história de qualquer língua, que advém do seu carácter arquitectural e diassistemático, recordamos a visão do tempo expressa por Rolf Eberenz: «Formarían entonces períodos históricos cada uno de los lapsos de tiempo en los que, después de un reajuste acelerado de las estructuras, se observase una prolongada fase de estabilidad» (Eberenz 1991: 93). Recordamos que se trata de um objetivo que, suscitado pela proposta de Evanildo Bechara (1991: 68-76), vimos perseguindo desde o começo da elaboração da nossa tese de mestrado (Carvalho 1996), onde demos conta da evolução de quatro aspectos morfológicos que permitiram delinear algumas "conjunturas linguísticas". Torna-se, no entanto, imperioso ampliar o leque de fenómenos (não só de natureza morfológica, eventualmente a área mais percetível na escrita, mas também de natureza gráfica, fonético-fonológica, sintática, semântico-discursiva e lexical).

Convém ter presente, porém, que houve variadíssimas mudanças linguísticas com carácter multissecular, cuja fronteira não é possível delimitar: o processo de simplificação das sibilantes, a elevação das vogais átonas pretónicas e postónicas (de um modo geral), a monotongação do ditongo [ow], os vários tipos de crase das vogais em hiato resultante da síncope de consoantes intervocálicas, o processo de convergência em - ão das terminações nasais, etc. processaram-se gradualmente ao longo dos tempos. Convém salientar que os fenómenos que iriam difundirse em épocas posteriores, pelo menos no texto escrito, tinham já desabrochado na fase mais antiga da língua. Recordamos, a título exemplificativo, que um documento de 1291 (1291 Alc 2) da coleção que transcrevemos e analisámos (Carvalho 2017a) apresenta aflorações de metafonia produzida por $u$ final sobre /e/; elevação de /o/ e /e/ em posição átona (final e interior); monotongação de $o u$; confusões gráficas a nível das sibilantes, indiciando o início de um processo de simplificação; neutralização da oposição /b/ /v/; crase das vogais em hiato; encontro das proclíticas em hiato com a vogal inicial da palavra seguinte; o moderno paradigma do presente do conjuntivo do verbo perder, etc. Conscientes dessa realidade, recordamos aqui o que, a esse propósito, afirmámos em 2002, ao tratar de questões de periodização da língua: 
fenómenos modernos alvoreceram em períodos marcadamente arcaicos e (...), ao invés, fenómenos de sabor arcaico continuaram a persistir, ainda que sob novas roupagens, em fases modernas e contemporâneas. Daqui resultam, inequivocamente, consequências de relevo na delimitação dos termos $a$ quo e ad quem dos marcos balizadores desses períodos: se, por um lado, é particularmente difícil datá-los com rigor, já que "as alterações lingüísticas não dependem do calendário nem do ano em que o século acaba ou começa" (Ali 1964: 8), por outro, será necessário operar com critérios de relativização, que é sempre correlata da heterogeneidade social que caracteriza qualquer comunidade de fala (Carvalho 2002: 16)

Resta-nos reconhecer que se em sincronia é difícil conceber cortes no espaço, em diacronia é, igualmente, difícil conceber a existência de cortes no tempo. A este propósito, é oportuno lembrar o que sobre periodização afirma Esperança Cardeira:

As propostas de periodização que escolhem como fronteira entre o português antigo e o português médio a crise de 1383-1385 ou o seu símbolo, a batalha de Aljubarrota, realçam o papel desta ruptura política, social e cultural no sentido da deriva linguística do português, mas parecem esquecer o facto de que as mudanças inovadoras já ocorriam antes desta data (Cardeira 2005: 291).

Ora, mesmo desconhecendo a que propostas de periodização a autora faz referência, a nossa análise dos textos antigos (cujos resultados têm sido divulgados desde 1996 até ao presente) bem como os dados aduzidos supra relativamente à cronologia do advento das inovações no nosso corpus vêm corroborar esta sua afirmação. Assim, e não obstante sabermos que, tal como na história social, económica e das instituições, as cronologias não coincidem simultaneamente para todos os fenómenos, e que «as inversões de conjuntura longa também não datam de um ano preciso simultâneamente para todos os produtos ou sectores, levam alguns anos a espraiar-se» (Godinho 19782: 15), é sempre possível «balisar [sic] franjas de separação mais ou menos largas temporalmente» (Godinho 1978²: 16).

Mesmo tendo consciência do artificialismo que qualquer divisão comporta, gostaríamos de apresentar a cronologia dos fenómenos linguísticos que se traduziram, na nossa amostra, em mudanças sistemáticas em cada época ou fase de transição. Há, como é sabido, casos em que as mudanças se manifestaram de forma fluida ou em que a escassez de dados não permitiu uma quantificação desejável para efetuar divisões claras. Na senda de Rosa Virgínia Mattos e Silva, cremos que «faz-se necessário (...) um estudo sobre um corpus único, cronologicamente seriado, sobre o qual se analisariam esses fatos ou esses e outros ou outros» (Silva 1994: 273). Por isso, fixámos como campo do nosso estudo um corpus de natureza notarial seriado cronologicamente e geo-socioculturalmente delimitado - uma coleção constituída 
por 153 documentos redigidos entre 1289 e 1565, por nós próprios transcritos (Carvalho 2017a), oriundos dos fundos do mosteiro cisterciense de Alcobaça ${ }^{4}$ uma vez que permite analisar a língua em diacronia e a continuidade da evolução discursiva. Embora não pretendendo rotular os diferentes períodos, apresentaremos uma divisão temporal mais fina, alicerçada na observação das mudanças ao longo do eixo diacrónico mencionado, em diferentes áreas de descrição.

\subsection{Português arcaico: $1 .^{\mathrm{a}}$ Fase (Até 1350/1360)}

Os fenómenos que iremos expor, comprovados estatisticamente ao longo dos vários artigos e comunicações que incidiram na análise do nosso corpus, sugerem que

não é a morte de um poeta, nem a riqueza económica de alguns poucos que devem ser vistas como causas da transformação de uma língua, mas sim alterações sociais que separam o português mais antigo de uma fase mais recente (Messner 1983: 239).

Esta época é caracterizada pelos seguintes fenómenos:

\section{Grafias}

- Representação da nasalidade através de grafema vocálico + $n$ em posição final (tónica e átona) ou ainda em formas monossilábicas (Carvalho 2018c: 168, 175): eftan, F(f)ernan, áálen, feen, an ('hão'), fan ('São', forma apocopada de Santo), por ex.

\section{Fonética-Fonologia}

- Formas verbais da $1^{\mathrm{a}}$ pessoa do Pretérito Perfeito do verbo põer, com $i$ final etimológico (<I): pugi, puggi, puffy, pugy, pugj (Carvalho 2005: 52 e 2019: 247).

- Coexistência entre formas onde se verificou a síncope de -N- (com formação de hiato e transmissão de nasalidade à vogal precedente) e formas que evidenciam o desenvolvimento de /n/ anti-hiático, nas terminações resultantes de -INU e -INA: uĩho $\sim$ vinho; vezĩo $\sim$ vezinho; lĩo linho. A generalização desta última solução verifica-se, de facto, apenas a partir de 1350 (Carvalho 2016c: 22).

\section{Sintaxe}

- Existência de formas proclíticas dos possessivos femininos $\int a(s)$ e $m h a(s)$. A variante $\int u a$ apenas aparece, pela primeira vez, em 1352, e a variante minha

4 Coleção Mosteiro de Alcobaça, $1^{\mathrm{a}}$ e $2^{\mathrm{a}}$ incorporações (IAN/TT). 
só surgiria, pela primeira vez, em1385. Curiosamente, a variante $m h a$ extingue-se num documento de 1388, pouco tempo depois de ter surgido pela primeira vez a variante moderna minha (Carvalho 2006: 492-493).

- Generalização das formas dos verbos seer (< SEDERE e ESSE) em estruturas descritivas de atributo semanticamente transitório. É só a partir de 1350 que seer e estar neste tipo de estruturas começam a surgir em variação: «que prefente foy» «que prefente estaua», por exemplo (Carvalho 2010a: 353-358).

- Generalização da lexia verbal deuer (com significado deôntico) regida de preposição a: deuer a (c. 55\%), apenas suplantada por deuer de ou deuer, a partir da data mencionada (Carvalho 2010b: 108).

Convém não esquecer, todavia, que houve dois aspetos inovadores que marcaram esta primeira fase: as terminações átonas das formas verbais procedentes de -ǓNT são já, maioritariamente, em -am, -an e -ã (Carvalho 2013b: 568) cronológico situado entre 1297 e 1350, 5 dos 9 documentos que contêm formas deste tipo apresentam estas terminações em 100\% das ocorrências; por outro lado, encontra-se generalizada (c. $75 \%$ ) a ênclise nos clíticos em frases afirmativas neutras, não dependentes ${ }^{6}$.

É muito provável, portanto, que a situação social precária da população rural que a peste negra (relativamente) poupou levasse essas pessoas a fugir para os novos centros urbanos, que passaram a constituir "“melting pots" de diversas formas linguísticas, mas também centros de irradiação da nova forma para as zonas circundantes» (Messner 1983: 239).

\subsection{Português arcaico: $2 .^{a}$ fase (até c. $\left.1380 / 1390\right)$}

Nas décadas que se seguiram a 1350, a par da mobilização social que eventualmente resultou da fuga à peste negra e/ou que precedeu o confronto de Aljubarrota, parecem ter-se realizado, igualmente, algumas mudanças que viriam a tornar-se sistémicas. Assim, esta etapa é caracterizada pelos seguintes fenómenos:

5 A evolução analógica que consistiu na propagação de -am, -an e -ã a formas evoluídas da terminação etimológica tónica -ONE (penfam por penfon, p. ex.) iria verificar-se a partir da década de 60 de Trezentos (Carvalho 2013b: 568). Temos apenas uma ocorrência anterior a essa data, o que se revela insuficiente para assinalar o início da mudança.

6 Só a partir de cerca de 1350 a próclise começa a suplantá-la estatisticamente, ao contrário, aliás, do que se verifica atualmente (Carvalho 2010c 125). 


\section{Fonética/Fonologia}

- Generalização da variante pẽa, com síncope de -N-. O desenvolvimento de $n$ como solução anti-hiática neste tipo de formas $($ PENA $>$ pẽa $>$ pea $>$ pena $)$ acontece a partir de cerca de 1380 (Carvalho 2016c: 18);

- Generalização das formas analógicas resultantes de FRŪCTU e seus derivados (de tipo froyto), tendo estas desaparecido a partir de 1383 (Carvalho 2018a: 50), em proveito das etimológicas fruyto/fruto;

\section{Sintaxe}

- Desaparecimento da forma feminina de possessivo $m \hbar$ a como variante de transição entre mha e minha (Carvalho 2006: 493). A partir de cerca de 1385, surge sempre a forma minha, em posição proclítica.

É entre cerca de 1350 e 1380 que se inicia o processo de adopção/difusão ${ }^{7}$ de um conjunto de outros fenómenos de relevo, a avaliar pelas primeiras abonações encontradas: monotongação de ei em [e], 1362 (a monotongação de ou começara já no século XIII) (Carvalho 2018a: 47); metafonia exercida por $u$ final sobre /o/ tónico (tudo, p. ex.) (Carvalho 2015c: 193); duplicações vocálicas sem fundamento etimológico nas terminações resultantes de -ONES (indiciando o processo de resolução do hiato vocálico, após a síncope de -N-) e afloramento (embora esporádico) da terminação -õs, uma outra solução para a resolução desse hiato, 1372 (Carvalho 2016c: 12); substituição de oi por ou em certos itens lexicais (coirela > courela, por exemplo), a partir de 1375 (Carvalho 2011b: 355); adoção do sufixo -inho aposto a bases antroponímicas (Joaninho, por ex., 1377) (Carvalho 2017c: 99) e início do processo de lexicalização de numerais, acompanhada de erosão fonética (perda da cópula e): dez oyto (1377), p. ex (Carvalho 2010-2011: 171).

\section{Léxico}

- Generalização do lexema filhar (60\% contra 33\% de tomar e 7\% de tirar), 'tomar conta de', 'apossar-se', que no período seguinte irá rivalizar, com tomar (Carvalho 2012: 596).

7 Recordamos aqui as fases da mudança linguística, segundo Eugenio Coseriu: «adoption (of an innovation by an individual), diffusion (adoption by several individuals), selection (alternating use of the older and the newer tradition), mutation (abandonment of one of the two traditions and the retention of the other, or establishment of a certain distribution of both traditions in the same "dialect" or eventually in different "dialects"». Cf: Eugenio Coseriu (1983), Linguistic Change does not Exist. In: Linguistica Nuova ed Antica. Rivista di Linguistica Classica Mediœvale e Moderna, Anno I, 56-57, ao qual não tivemos acesso. Apud: Maia 1994: 38, nota 11. 


\subsection{A "elaboração" da língua portuguesa (1380/1390-1425/1430)}

De acordo com Esperança Cardeira (2005: 291), «os resultados obtidos comprovam que a primeira metade do século XV materializa uma transição de fase», pelo que assistimos durante esse período à elaboração do português» (Cardeira 2005: 291).

Os resultados da análise do nosso corpus sugerem que foi entre 1383/1385 e 1425 que se registou o início do processo de elaboração da língua, no sentido da estandardização ${ }^{8}$. Ou seja, o primeiro quartel do século XV faz parte de uma conjuntura linguística que começou nos últimos anos do século anterior, não nos parecendo tão rigoroso, à luz dos nossos dados, integrá-lo de modo estanque, sob o ponto de vista do devir histórico da língua, apenas na primeira metade do século XV.

Em primeiro lugar, ao nível gráfico, regista-se uma preocupação no sentido da "correção" que, ora se traduz em experiências novas (por fenómenos de analogia), ora em tentativas de recuperação latinizante:

\section{Grafias}

- Difusão da grafia th na forma teor e nas derivadas de teer (theor e theudo, p. ex.), eventualmente como incorreta colocação de $h$ por analogia com as formas em que ele inicialmente surgia com função anti-hiática (Carvalho 2018b: 45);

- Difusão da grafia etimológica $b b$ na forma abade (90\%) bem como do grafema composto gu seguido de $a$, eventualmente por analogia com gue e gui (Carvalho 2018b: 48);

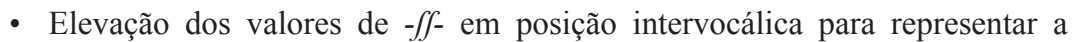
sibilante surda (Carvalho 2018b: 53);

- Elevação dos valores de $f(f)(97 \%$ contra 3\% de $u / v)$ em formas historicamente representantes de PROFĔCTU e derivados (Carvalho 2018b: 60).

Apresentam-se a seguir as mudanças linguísticas observadas, neste período:

\section{Fonética-Fonologia}

- Surgimento das grafias pllo, plla e pla, deixando adivinhar a redução e fechamento de e em sílaba átona (Carvalho 2015d: 61);

8 Corresponde grosso modo ao reinado de D. João I, precursor da dinastia de Avis, e, no mosteiro de Alcobaça, a uma grande parte do abaciado de Frei João d' Ornelas, caracterizado por um forte peso normativo na grafia da produção documental, não obstante as inúmeras mudanças que se desenvolveram, nesta fase. 
- Difusão de casos de metátese entre $l$ e $r$, particularmente na forma historicamenterepresentante de CLĒRǏCU (creligo por clerigo); inversamente, tendência (por influência culta) para a manutenção de PL- na forma historicamente derivada de PLACĬTu (plazo, arc.) (Carvalho 2016a: 132-133);

- Início da difusão da neutralização da oposição $/ \mathrm{b} / \sim / \mathrm{v} /$ em posição inicial, fenómeno que seria acentuado no segundo quartel do século XV : beria, binho, bifto, por ex. (Carvalho 2011a: 148);

- Início da eliminação de um grande número de hiatos, após a síncope de consoantes intervocálicas: crase das vogais centrais em posição pretónica em formas de tipo gaanhar e variantes flexionais (gaanhar > ganhar); desaparecimento das plicas sobre áá(s) (resultante do encontro de proclíticas em hiato com a vogal seguinte), fazendo supor a consumação da crase, neste contexto; fusão das duas vogais anteriores fechadas (tónica e pretónica), quando precedidas de /v/ (viinte > vinte); geminação gráfica de $a$ sem fundamento etimológico nas terminações dos plurais dos nomes de lexema em - $l$ precedido de $a$ tónico (-ááes; -aaes), indiciando a resolução do hiato vocálico, neste contexto (Carvalho 2016c: 27, 31, 36);

\section{Morfologia}

- Difusão (cerca de 40\%) das terminações em -ido de particípios do "primeiro grupo" (Carvalho 2019: 239) dos verbos em -er (requerido, vendido, corregidas, etc.): a consumação da substituição de -udo por -ido neste grupo participial iria acontecer na etapa seguinte ${ }^{9}$;

- Adoção/difusão de formas do tipo trazer com radical TRAZ- (que irão substituir trager, com radical TRAG-), embora no segundo quartel do século XV ainda se encontre uma ocorrência com o antigo radical (Carvalho 2019: 248).

- Adoção da forma derivada melhoramento, que irá destronar melhoria na $2^{\mathrm{a}}$ metade do século XV (Carvalho 2015a: 387).

- Início da variação entre formas com e sem prefixo $a$ : apenhorar (tendência já antiga na língua) penhorar. Esta última variante viria a vingar na segunda metade do século $\mathrm{XV}$, embora na linguagem jurídica o prefixo tenha sido recuperado, eventualmente já no português contemporâneo, criando-se uma especialização semântica com o par apenhorar/penhorar (Carvalho 2016b: 52-53).

9 Distinguimos três fases na mudança da terminação participial - udo para -ido, consoante os fonemas consonânticos que precedem a vogal temática (Carvalho 1999-2000: 407-408). Na verdade, dados de outro tipo de textos (tradução galega da General Estoria, livros de caráter religioso e moralístico) provam que o fenómeno já estava aí implementado no século XIV (idem, ibidem: 404). 
Extinção de formas verbais descendentes de verbos incoativos, preservando -SC-. O último exemplo do nosso corpus data de 1399 (cognosco) (Carvalho 2019: 246).

\section{Sintaxe}

Mudança (irreversível) a nível dos possessivos femininos em posição proclítica: $m h a / m \hbar a$ dão lugar a minha; $s a(s)$ (convertida de SUA, já no latim coloquial tardio) extingue-se em proveito de fua/sua (Carvalho 2006: 495);

Complementação preposicional com de (substituindo $a$, do período anterior) na lexia verbal deuer (com significado deôntico): deuer de. O retomar dessa tendência, afastada hoje da norma portuguesa, verificar-se-ia na década de 80 do século XV (Carvalho 2010b: 108);

\section{Semântica}

Elevação máxima dos valores de auer em estruturas de posse, atestando uma forte pressão normativa com vista à estandardização (Carvalho 2014a: 360). De facto, auer deveria ser nesta altura entendido como mais neutro, menos próximo do sujeito. Este afã de erudição foi de tal forma acentuado que documentos de 1380 e 1383 oriundos dos coutos (Alvorninha e Aljubarrota) registam, por ultra-correção, «por bem ouuer», expressão que, ao longo do período medieval, conheceu sempre o verbo teer: «ter por bem» (Carvalho 2014a: 353);

É, igualmente, nesta fase, que alguns fenómenos que marcam dialetalmente o Portugal de hoje, que o distanciam (ou aproximam, no caso do galego) de outras línguas românicas ou ainda que constituíram, na época, ultracorreções, começam a aflorar: início da propagação da terminação nasal -õ/-om a formas com terminação etimológica -ã/-am (ultracorreção dialetal, hoje ainda preservada no norte de Portugal, que se irá difundir na fase seguinte: pom por pam, p. ex.) (Carvalho 2013b: 574-575); início do processo de desnasalização nas terminações tónicas que perderam o -N-: capoef, cõdiçooes, obrigações, campaa, chaao (Carvalho 2016c: 38-44); aparecimento de formas de gerúndio pessoal, à semelhança das de infinitivo pessoal («e vendam feus vinhos fem pagãdo deles (...), 1391 MA 59) (Carvalho 2015b: 676); o emprego do Condicional pelo Imperfeito em verbos de conteúdo inteletual ou cognitivo, ou seja, em contextos onde seria mais natural o uso deste

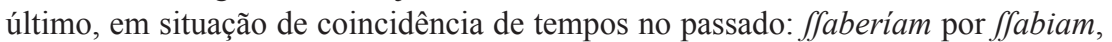
p. ex (Carvalho 2017b: 101). Curiosamente, é nesta fase que surgem os primeiros exemplos de mesóclise: «e uos darnofedes» (1386; 1397 e 1399) (Carvalho 2010c: 121 e 2014b: 275), o que denuncia uma clara consciência da composicionalidade ou caráter analítico da formação de formas do Futuro. É nesta fase, também, que se 
regista o termo a quo da estrutura delocutiva dos "Prazos" (1416) (Carvalho 2006: 642-643 $)^{10}$.

Por um lado, 1380 é o termo a quo de inúmeras mudanças sistémicas:

- Generalização de $<\mathrm{i}>$ em substituição de $<\mathrm{y}>$ para representar a semivogal (Carvalho 2018c: 162). A partir de cerca de 1380, <y> é, de facto, substituído por $<\mathrm{i}>$, embora aquele grafema ressurja nos últimos anos do século XVI, nesse contexto.

- Transformação da fricativa ápico-alveolar do étimo SERRARE para dorsoalveolar, que começa a aparecer graficamente representada por $c$ (serrado transforma-se em cerrado), transformação que afetaria, eventualmente, outros itens lexicais nas mesmas circunstâncias (Carvalho 2011a: 146);

- Difusão do verbo estar nas estruturas locativas absolutas (ex: «que jazẽ e eftam em hũa herdade», p. ex.) (Carvalho 2010a: 363).

Por outro, 1425 é o termo ad quem de outros fenómenos (quer de natureza gráfica, quer linguística):

- Representação da fricativa prepalatal sonora /3/ pela grafia $i$ (a partir de 1425, $i$ cede lugar a $j$ ) (Carvalho 2018b: 57);

- Grafia ẽ, em formas monossilábicas, sendo, a partir daí, substituída por em (Carvalho 2018c 177).

- Acentuação proparoxítona latina na forma de Presente de Conjuntivo sabham (a partir desta altura, regista-se a atração da vogal para junto da sílaba tónica, formando com ela um ditongo, transformando-se a forma verbal em paroxítona: saibam) (Carvalho 2018a: 44-45);

- Variação entre filhar e tomar (50\%/50\%), extinguindo-se a primeira a partir de 1425 (Carvalho 2012: 596).

Uma visão de conjunto da situação linguística apresentada revela, sem sombra de dúvida, que ao terminar o primeiro quartel do século XV, a língua portuguesa despia os trajes medievos. A par de uma intensa elaboração da língua, surgem já indícios de que uma forte consciência do seu devir temporal (manifestada por fenómenos de ultra-correção) começava também a delinear-se.

O marco histórico significativo que promove a viragem do português antigo para o português moderno é inquestionavelmente a revolução de 1383-85. Desde aí

10 Sobre estruturas alocutivas e delocutivas, veja-se Charaudeau 1992: 574-576. O termo ad quem das primeiras estruturas verifica-se apenas no terceiro quartel do século XV (Carvalho 2017a). 
estrutura-se, efetivamente, uma outra "conjuntura linguística", vivificada pelos novos quadros sócio-económicos. Recordando o que afirmámos em 2002:

Se tivéssemos que escolher um marco histórico significativo para assinalar a verdadeira viragem do português arcaico para o português moderno, não hesitaríamos em apontar a revolução de 1383-1385, momento que fez surgir, despoletada pela mobilidade sócio-geográfica do Povo e da empreendedora burguesia lisboeta, uma nova ordem social (Carvalho 2002: 24).

Por outro lado, procurámos deixar claro que há muitos fenómenos que elegem a data de 1425 aproximadamente como seu termo a quo e ad quem, o que torna pouco rigorosa a afirmação de E. Cardeira, para quem «a primeira metade do século XV materializa uma transição de fase» (Cardeira 2005: 291).

\subsection{Da "elaboração" da língua portuguesa à estandardização: a transição (1425/1430-1450)}

A instabilidade política que se iria viver após o declínio do reinado de D. João I, e que desembocaria no desastre de Alfarrobeira, traduziu-se num forte relaxamento normativo ao nível dos textos escritos no mosteiro de Alcobaça. Convém, no entanto, salientar que o pequeno número de documentos de que dispomos é, maioritariamente, periférico, oriundo dos coutos, o que poderá condicionar os resultados obtidos. Não deixa, contudo, de ser interessante concluir que alguns fenómenos se observam, em exclusividade, nesta fase. Em alguns casos, entrevêem-se diferentes particularismos linguísticos socio-regionais, que irão ser transportados para outros continentes:

\section{Grafias}

Surgimento de novas experiências, bastante afastadas do ideal de estandardização. São desta época as grafias $t t, d h, g e / g i$, bem como $\iint$ a entravar sílaba, todas registadas em documentos de periferia e cedo abandonadas (Carvalho 2018b: 46, 48, 54);

\section{Fonética-Fonologia}

Afloramento (embora de forma isolada) de anaptixe de vogal $i$ em grupos consonânticos (pobiricafe, 'publicasse'), indiciando, assim, não se tratar de um traço autóctone do português do Brasil (Carvalho 2016a: 134);

- Surgimento de [j] (embora de forma isolada) em terminações resultantes de -ENA, como forma de resolução do hiato, após a síncope de -N-: (LEIRENA > Leirea > Leirja, p. ex (Carvalho 2016c: 18). 
- Generalização da crase das vogais pretónicas na forma moefteiro: mofteiro (sem que se registe a fase de transição: oe > oo) (Carvalho 2016c: 34);

- Consumação da crase das vogais centrais pretónicas em formas do tipo gaanhar, processo iniciado na etapa anterior (Carvalho 2016c: 27);

- Difusão acentuada da neutralização da oposição /b/ /v/ em posição inicial, que parece ter desaparecido gradualmente a partir de 1450: birẽ, bynte, bidas, balham, biefe, Bjçẽte, por ex. (Carvalho 2011a: 148);

- Substituição (87 \%) de -vil (cujo termo ad quem é 1450) por -vel (<-BĬLE) (Carvalho 2015d: 68);

- Difusão de algumas hipercorreções dialetais que tiveram início na fase anterior, como a propagação da terminação nasal õ/om a formas com terminação etimológica ã/am (Carvalho 2013b: 574-575).

É nesta fase que desabrocham, por outro lado, algumas transformações que se irão consumar na etapa seguinte, motivo pelo qual decidimos rotulá-la como "período de transição":

- Fechamento de $e$ pretónico em $i$ quando aquela vogal, em hiato com a vogal seguinte, se encontra precedida de dental (adiante, p. ex), fenómeno que iria atingir os valores máximos a partir de 1450 (Carvalho 2015d: 63-64);

- Difusão da crase de vogais centrais (tónica e pretónica), quando precedidas de fonema fricativo labiodental: Vaafco $>V a f c o$, p. ex. (Carvalho 2016c: 25-26);

- Crase das vogais em hiato (após a síncope de -N-) nas terminações resultantes de -ANA-: quintãa > quintã (Carvalho 2016c: 6);

- Crase de vogais anteriores fechadas (pretónica e tónica), em triinta > trinta (Carvalho 2016c: 30-31).

- Variação pedir pidir, ambas atingindo, a partir desta altura, valores muito semelhantes (50\%/50\%) (Carvalho 2015d: 59);

- Início da redução e síncope de $e$ nasal átono pretónico na forma nẽhũu, manifestada em grafias do tipo nhũu (Carvalho 2015d: 62);

- Difusão de $i$ (não etimológico) em posição átona final: quiti, ljuri, por exemplo, que caracteriza atualmente o Português do Brasil (Carvalho 2005: 53). Este fenómeno estava já em incubação na fase arcaica, mas não foi implementado nessa altura.

\section{Morfologia}

- Consumação da substituição participial -udo por -ido nos verbos de $2^{\mathrm{a}}$ conjugação ( $1^{\circ}$ grupo), difundida na etapa anterior (Carvalho 2019: 239); 
Adoção das formas da série do Perfeito de (a)prazer que resultaram da ação analógica do Perfeito houve: aprouve, p. ex. e início da variação aprougue aprouue (Carvalho 2019: 252);

- Adoção das formas com dissimilação de vogal $o$ pretónico nas formas flexionais e derivadas de conhocer (conhocer > conhecer), e consequente início da variação (Carvalho 2019: 246);

- Adoção do prefixo $a$ - nas formas do Perfeito do verbo (a)prazer: aprouguer, aprouuer, etc. (Carvalho 2016b: 49-50) e extinção do mesmo prefixo na forma verbal aguardar (Carvalho 2016b: 53); o seu ressurgimento neste último item lexical, aliado às conhecidas restrições semânticas, deverá ser um fenómeno posterior ao século XVI.

Início da difusão da terminação sufixal -çõ/-çom ('-ção') em alguns itens lexicais, exprimindo quer o aspecto eventivo quer o resultativo (ao contrário de -mento, cujos derivados eram exclusivamente eventivos): «fob obrigaçom» vem substituir «fob obrigamento», por exemplo, sendo igualmente usado na expressão nominal «inftrumento de obrigaçõ» (Carvalho 2015a: 384-386);

\section{Sintaxe}

- Generalização do verbo estar em estruturas descritivas de atributo semanticamente transitório: «eftando hy o muyto honrado» (Carvalho 2010a: 360);

- Generalização da estrutura depois de (depois seleciona o complemento através de preposição), transformando-se, assim, um advérbio em locução prepositiva, tal como acontece no português contemporâneo (Carvalho 2010b: 107-108).

- Adoção de formas de Infinitivo flexionado em construções selecionadas por verbos do tipo mandar («fazer parar» 'impedir'): «ẽquãto lhes tẽpo nõm fyzer parar vyrẽm ao mar» (1437 Ped 94) (Carvalho 2015b: 687);

Surgem, igualmente, nesta fase, algumas inovações sintáticas:

- Uso do Infinitivo impessoal com valor de Imperativo, em contextos em que o infinitivo flexionado seria mais natural: «e as adubedes todas em cada hũu anno bem e ffyelmente a fleus tẽpos e sazoes: deffcauar e podar e empaar e amjrgulhar e cauar e arrendar» (1450 Alv 104) (Carvalho 2015b: 673);

- Uso do Imperfeito do conjuntivo em construções em que, normalmente, se usava o Infinitivo flexionado. Neste último caso, tratou-se de uma inovação surgida quando os documentos deixaram de ter uma estrutura de tipo alocutivo (dialógico) e passaram a ter uma estrutura delocutiva ${ }^{11}$, tendo decorrido de

11 Charaudeau 1992: 574-576. 
um desejo de levar até às últimas consequências a observação da "consecutio temporum" (uma vez que se incluiu no início do documento o fulcro verbal «disse que»/«foi dicto que»): «e logo por os fobre dictos cõçelho e homẽs e procuradors foy dicto $q[u e]$ (...) e pagada $<$ a dicta $>$ pena ou nõ toda uja a dicta auẽça fofe firme e eftauell (...) e fe cõp[r]iffe pella gjfa que dicto he» (1434 SC 91) (Carvalho 2015b: 674-675) . $^{12}$

Surgimento da estrutura teer + Particípio Passado não-flexionado, ou seja, teer como auxiliar em estrutura de tempo composto (Carvalho 2013a: 48);

\section{Semântica/Discurso}

Foi nesta fase de transição que começou a delinear-se uma clara consciência da composicionalidade das palavras:

Aparecimento de advérbios em -mente, com separação gráfica dos seus elementos constitutivos (Carvalho 2010-2011: 169-170); de igual modo, verifica-se a separação dos mesmos em formas onomásticas (Aljuba Rota, p. ex.) (Carvalho 2010-2011: 172);

- Difusão de processos de lexicalização de numerais (com omissão da cópula $e$ e subsequente erosão fonética): dez ojto/dezooyto (Carvalho 2010-2011: 171);

- Em numerais com o elemento cento, início da variação entre formas que apresentam a união e as que apresentam a separação desse elemento ao outro cardinal: quatro çentos quatroçentos, por exemplo (Carvalho 2010-2011: 171-172);

Tendo em conta que se trata de mudanças que ocorrem exclusivamente neste período, época caracterizada por um abrandamento da pressão normativa emanada deste centro monástico e em que os documentos são maioritariamente redigidos nos coutos, pode dizer-se que se trata de transformações "from below", eventualmente estigmatizadas por quem detinha o poder cultural. Curiosamente, algumas delas (como a passagem $o e>o$ em moefteiro ou a generalização de estar em estruturas descritivas de atributo semanticamente transitório) voltariam a ser refreadas a partir de 1450 e com nova tentativa normativa restauradora verificada no mosteiro de Alcobaça.

Trata-se, assim, de um período em que se difundem ou consumam definitivamente algumas transformações já em voga na etapa anterior. Sobre esta fase, pronunciámo-nos deste modo, a propósito de um amplo corpus textual:

12 Essa observação da concordância dos tempos nem sempre era observada, como documenta o exemplo seguinte, relativamente coevo: «E o dicto senhor (...) lhes perdoou com efta condiçom que elles nem nẽhũu delles nom fofem mais cõtra elle nẽ cõtra feus foros e cuftumes nẽ em outra nemhũa coufa femelhante ante lhe fler]eem bem obidientes (...) e amõtarem fenpre» (1436 Alf 93). 
Ainda que a variedade de prestígio estivesse já bem definida nos textos do primeiro quartel do século XV, a "selecção" continuou a processar-se até cerca de 1450, configurando, assim, uma fase de "transição da língua medieval para uma plataforma estável” (Castro 1991: 243) (Carvalho 2002: 24).

\subsection{O Português (pré-) moderno: da codificação normativa aos “dialectalismos" ${ }^{13}(1450 / 1460-1485)$}

Quando, depois do acidente de Alfarrobeira (1449), D. Afonso V põe termo às crises e lutas que se vinham arrastando desde o século anterior, a língua parece entrar definitivamente numa «plataforma estável» (Castro 1991: 243). Do ponto de vista socioeconómico, essa "estabilidade" linguística acompanhou a inversão de rumo do país: as conquistas africanas, o triunfo do neo-senhorialismo, o começo da repercussão da expansão ultramarina na vida da Metrópole, bem como o adensar das redes sociais motivado pela ascensão da curva demográfica, foram decisivos para a consolidação da língua. Também nesta fase, e não obstante a tendência registada para a estandardização (tal como a entendemos hoje), acentuam-se alguns traços, particularmente de natureza fonética, que irão caracterizar o Português do Brasil e outras variedades do Português. Assim, a partir de meados do século XV, com a abertura da Metrópole a uma escala transcontinental, são as seguintes as mudanças registadas:

\section{Grafias}

Generalização do grafema $j$ (para a representação da fricativa prepalatal sonora) a contextos em que esta consoante vem seguida de $e$ ou $i$ : monje, p. ex. (grafia que não é, aliás, idêntica à do português atual) (Carvalho 2018b: 58);

Exclusividade da variante aproveitar, com $v$ em vez de $f$ (Carvalho 2018b: 60);

\section{Fonética-Fonologia}

- Emprego de $l l$ a entravar sílaba ou palavra, suplantando os valores de $l$, na mesma posição (56,7\% entre 1450 e 1485, mantendo-se estável a partir daí). Trata-se de um indicador que permite diagnosticar a tendência para a velarização da lateral, traço que seria transportado para o continente americano (Carvalho 2016a: 129-130);

- Proliferação de casos de $i / j$ (não etimológico) em posição átona final: presentj, diantj, estj (Carvalho 2005), que seria depois transportado para o continente americano.

13 A noção de "dialectalismo" é, naturalmente, uma noção criada pelo investigador atual, pois não existiria para o falante da época. 
Consumação do fechamento de $e$ pretónico em $i$ quando aquela vogal, em hiato com a vogal seguinte, se encontra precedida de dental: adiante, p. ex. (Carvalho 2015d: 64); do mesmo modo, resolução do hiato entre duas vogais anteriores médias (pretónica e tónica) através do fechamento da primeira: pardeeiro $>$ pardieiro, p. ex. (Carvalho 2015d: 65);

- Consumação da crase das vogais centrais (pretónica e tónica), em formas do tipo Vaafco > Vafco, p. ex. (Carvalho 2016c: 25-26);

- Consumação da assimilação de vogal pretónica no representante histórico de TABELIŌNE (tabaliõ), contrariando a tendência etimológica da norma linguística atual (Carvalho 2006: 361).

- Proliferação da indistinção entre os grafemas $i$ e $e$ em posição postónica, tendência que permite diagnosticar a equivalência fónica entre os dois

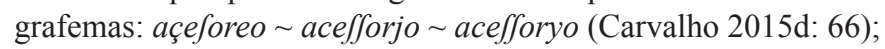

- Elevação da vogal pretónica nos representantes históricos de PŌMAR (pumar, arc.) e LŎCĀLE (lugar), mudanças registadas a partir de 1460, e proliferação das hesitações na fixação gráfica da semivogal nos ditongos crescentes: Agoas, augoa, auguoa, p. ex. Ambos os fenómenos são indicadores da elevação de [o] para [u] em posição átona (Carvalho 2015c: 183 e 187);

- Proliferação das confusões gráficas na representação das sibilantes (apicais e dorsais) (Carvalho 2011a: 143-144);

- Metátese na forma bachaler, de origem francesa $(<*$ BACCALARU-), que originou a forma (não etimológica) bacharel (Carvalho 2017a) ${ }^{14}$.

- Desaparecimento de $l$ no advérbio folamente (a partir de 1460), eventualmente um moçarabismo fonético (Carvalho 2016a: 138-139);

- Difusão da solução -õos como resolução do hiato criado com a síncope de -N- na terminação -ONES. Saliente-se que -õs surge, pela primeira vez, num documento de 1372 ( $2^{\mathrm{a}}$ fase do português arcaico), na forma quartejrrõs (Carvalho 2016c: 11-12);

- Simplificação do hiato em terminações resultantes de -ENES (profusão de grafias do tipo beens, beẽs, bẽs, bẽns) (Carvalho 2016c: 19-20);

- Proliferação de casos de fonética sintática que resultam do encontro da preposição ou artigo a com a vogal inicial do nome seguinte: «hõde moreo Allquoffora» ('onde morreu a Alcofora') (Carvalho 2006: 340);

- Crase das vogais anteriores fechadas em formas do tipo triigo ( $>$ trigo) e cabiido (> cabido), p. ex. (Carvalho 2016c: 31-32);

14 Por lapso, não incluímos este fenómeno no trabalho de 2016a. A nossa pesquisa permitiu concluir que esta mudança se verificou a partir de 1450 . 
- Difusão do desenvolvimento de semivogal como solução anti-hiática nos plurais de lexema em $-l$ precedido de $e$ átono: moveis, p. ex. (Carvalho 2016c: 37);

- Conclusão da convergência sistémica das terminações nasais em -am, com difusão desta terminação a formas ditas "gramaticais" (nam, entam, etc.) (Carvalho 2013b: 571);

- Últimos vestígios da forma etimológica foy $(<$ FǓī $), 1^{\text {a }}$ pessoa do Pretérito Perfeito de ESSE (Carvalho 2006: 376), sem metafonia.

\section{Morfologia}

Adoção de formas verbais com perda de $-d$ - no morfema número-pessoal. A consumação do fenómeno dar-se-ia apenas a partir da década de 80 deste século $^{15}$ (Carvalho 2019: 242-243);

- Difusão da forma derivada aforamento, como solução para a ambiguidade polissémica de foro (a partir de 1460) (Carvalho 2015a: 375-379);

- Mudança do significante prefixal $f$ - para ef- (com vogal de suporte): efpedaçar. Trata-se, eventualmente, de ultra-correcção, como reacção à perda do prefixo $a$ - em ítens lexicais como aguardar. De facto, a partir desta fase, encontra-se a forma efguardar, em alguns documentos (Carvalho 2016b: 60);

- Extinção da forma verbal conhocer (e derivadas), com o etimológico (Carvalho 2019: 246);

- Extinção do sufixo -mento em proveito de -ção, aposto à base obrigar (obrigaçom substitui obrigamento em todos os contextos) e do sufixo -ia em proveito de -mento, aposto à base melhor (melhoramento substitui melhoria, no mesmo contexto) (Carvalho 2015a: 384-387);

- Extinção do prefixo $a$ - em apenhorar (Carvalho 2016b: 53);

\section{Sintaxe}

- Consumação de estar como auxiliar exprimindo o aspeto concluído (estar + Particípio): «que ora efta ja pofto» (Carvalho 2010a: 367);

- Difusão do Infinitivo flexionado a estruturas com verbos de tipo performativo: obrigar-se [a], outorgar e prometer (Carvalho 2015b: 684-685);

15 A Virtuosa Benfeitoria do Infante D. Pedro, O Livro da ensinança de bem cavalgar bem como o Leal Conselheiro, de D. Duarte, já não conhecem o morfema -des. Na prosa cronística de Fernão Lopes, tudo leva a crer que esteja formada uma clara consciência do cunho feminino e popular de -des (Carvalho 2000: 70). 
Adoção de formas de Infinitivo flexionado em orações infinitivas completivas com verbos declarativos (Ex: diferão ferem bem cõtemtes») (Carvalho 2015b: 686-687);

- Termo ad quem da estrutura de tipo alocutivo/dialógico dos documentos ("Prazos"), que é substituída pela estrutura delocutiva (Carvalho 2006: 642643).

- Extinção de formas de Imperfeito do indicativo procedentes do verbo SEDERE, em estruturas descritivas de atributo semanticamente transitório: a última forma arcaica encontrada data de 1467 (Mai 117): «leuãtãdofe logo o dito senhor donde fya» (Carvalho 2010a 356).

\section{Semântica-Léxico-Discurso}

- Difusão de teer a expressões tautológicas de natureza formular («teer e manteer») (Carvalho 2014a: 358);

- A nível dos pontos cardeais, difusão da forma vendaval («vent d'aval»), de origem francesa, que substitui aurego, e de ponente/poente, que substitui traueffia (Carvalho 2012: 597-598);

- Ao nível do campo semântico da "morte", substituição do particípio fraco finado pelo particípio forte findo, e do nome eufemístico acabamento por falimento (Carvalho 2012: 599-600);

- Consumação da lexicalização de numerais: a cópula $e$, que liga numerais cardinais, sofre erosão fonética, sendo substituída por um elemento mais forte: dezafejs substitui dez e seys, p. ex. (Carvalho 2010-2011: 171).

Importa salientar que no período compreendido entre 1450 e 1485, aproximadamente, verifica-se novamente, na coleção em análise, um esforço de estandardização, agora não só ao nível gráfico, mas também morfossintático. É neste período que atingem os valores mais elevados os seguintes fenómenos:

Grafia $\iint$ em posição inicial e $\sigma$ em posição final; contraditoriamente, $\iint$ atinge, nesta fase, os valores mais elevados na representação da sibilante sonora intervocálica. A consciência da distinção entre surda e sonora e da necessidade da existência de grafemas diferentes para a sua representação poderá ter levado a este tipo de ultracorreções (Carvalho 2018b: 52-53).

- Uso do grafema $j$ em jgreja, destronando o até aí habitual e (jgreja substitui egreja) (Carvalho 2015d: 49);

- Uso da forma "prazo", em detrimento de "emprazamento", eventualmente como tentativa de decalcar o arquétipo etimológico latino (Carvalho 2015a: $371)$; 
- Estrutura obrigar de (V + complementação preposicional) mas, curiosamente, deuer ø e depois ø (sem complementação preposicional), o que traduz diferentes graus de consciencialização quanto à função sintática da preposição. (Carvalho 2010b: 106; 108-109).

\subsection{O Português moderno (1485-...)}

Algumas mudanças efetuar-se-iam apenas a partir da década de 80 do século XV, ao soprarem na cultura portuguesa os ventos do humanismo italiano, e ao estabelecer-se o capitalismo comercial a uma escala transcontinental, favorecido pela nova rota do Cabo. Deixam de se verificar a partir daqui as forças centrípetas normativizadoras, verificando-se, assim, a "desnacionalização" da língua, que irá ser transportada, com as colorações próprias que lhe emprestavam os que se aventuraram a cruzar os oceanos, para os mais diversos continentes. Essas mudanças, que coincidiram com a penetração dos caracteres móveis de Gutenberg, foram as seguintes:

\section{Grafias}

- Difusão de $s$ (em detrimento de $\int$ ) em posição inicial e intervocálica (Carvalho 2018b: 52-53);

- Difusão de $v$, em detrimento de $u$, em posição inicial (Carvalho 2018b: 61);

\section{Fonética-Fonologia}

Difusão de grafias apresentando ausência de e pretónico, deixando adivinhar uma pronúncia bastante relaxada da vogal nessa posição ou mesmo o seu desaparecimento (acõtçer, p. ex.) (Carvalho 2015d: 61);

- Elevação dos valores da crase em moefteiro (> mofteiro), retomando o ritmo da fase "de transição" 1426-1450 (Carvalho 2016c: 34);

\section{Morfologia}

- Elevação dos valores da crase nas formas de plural de nomes de lexema em $l$ precedido de $e$ átono: moves, p. ex. (fazendo supor uma evolução do tipo movees $>$ moves) (Carvalho 2016c: 36-37);

- Mudança das terminações participiais em -udo para terminações em -ido nos verbos de segunda conjugação, com fonema fricativo labiodental ou bilabial a preceder a terminação participial ${ }^{16}$ (2 $2^{\circ}$ grupo: avudo > avido, p. ex.) (Carvalho 2019: 239);

16 Nos textos literários, este tipo de evolução segue muito mais de perto a evolução registada em verbos do grupo 1 (com fonema alveolar ou palatal a preceder a terminação). De facto, os particípios em -ido 
Consumação da síncope de $-d$ - intervocálico nas formas verbais de segunda pessoa do plural (Carvalho 2019: 242-243);

- Surgimento (sistémico) do morfema - a nos nomes terminados em -or (senhora, por exemplo) (Gouveia e Carvalho 2019: no prelo);

\section{Sintaxe}

- Ressurgimento das estruturas deuer de (com valor deôntico) e depois de (com complementador preposicional de) (Carvalho 2010b: 108-109);

\section{Semântica-Léxico-Discurso}

Supremacia de teer sobre auer em todo o tipo de estruturas de posse (Carvalho 2014a: 360);

- Generalização do item verbal tirar (75\%), em detrimento de tomar (Carvalho 2012: 596);

- Substituição dos lexemas designativos de pontos cardeais foam e aguiom por Levante e Norte, respetivamente (Carvalho 2012: 597-598);

- Substituição dos produtos nominais falimento/acabamento por falecimento, designativos de 'morte' (Carvalho 2012: 600);

- Aparecimento do valor adversativo do conetor porem, que deixa de ter valor explicativo-conclusivo (Carvalho 2010-2011: 168-169).

Eventualmente como ultracorreção, no século XVI surgem formas de Futuro do Pretérito em expressões parafraseáveis por "talvez + Imperfeito do Conj.”, ou seja, em contextos de modalidade epistémica: «em o qual avyria ['talvez houvesse'] quinze ou dezafejs pees d'oliveyrras» (1502 MA 137), p. ex.

\section{Conclusões}

Mesmo tendo consciência do carácter fragmentário e textualmente não diversificado de um corpus como o que analisámos (Carvalho 2017a), apresentaremos, na tabela seguinte, o termo ad quem dos fenómenos (incluímos alguns do plano da grafia) ${ }^{17}$ que, no nosso corpus, apresentam um limite cronológico idêntico ou muito próximo:

neste $2^{\circ}$ tipo já prevalecem no Livro da ensinança de bem cavalgar, de D. Duarte. A distância temporal entre as linhas evolutivas de ambos, tendo em conta a sua implementação no sistema, é bastante mais acentuada na prosa notarial da zona Centro-litoral portuguesa (Carvalho 2019: 239).

17 Os fenómenos de natureza gráfica (mesmo quando têm implicações linguísticas pertinentes) encontram-se separados dos fenómenos linguísticos por uma linha. 
Tabela n. ${ }^{\circ} 1$ - Cronologia (termo ad quem) de alguns fenómenos gráficos e linguísticos, no corpus analisado

\begin{tabular}{|c|c|c|c|c|}
\hline c. 13 & c. $1380 / 1390$ & c. $1425 / 1430$ & c. $1450 / 1460$ & c. 1485 \\
\hline $\begin{array}{l}\text { Formas verbais } \\
\text { da } 1^{\text {a }} \text { pessoa do } \\
\text { Pretérito Perfeito } \\
\text { do verbo põer, } \\
\text { com i final } \\
\text { etimológico (<i): } \\
\text { pugi, puggi, puffy, } \\
\text { pugy, pugj } \\
\text { Variação entre } \\
\text { formas onde } \\
\text { se verificou a } \\
\text { síncope de -N- } \\
\text { (com transmissão } \\
\text { de nasalidade à } \\
\text { vogal precedente) } \\
\text { e formas que } \\
\text { evidenciam o } \\
\text { desenvolvimento } \\
\text { de /n/ anti-hiático, } \\
\text { nas terminações } \\
\text { resultantes de } \\
\text {-INU e -INA: uĩho } \\
\text { uinho; uezĩo } \\
\text { uezinho, camĩo } \\
\text { caminho, etc. } \\
\text { Generalização } \\
\text { do verbo seer } \\
\text { em estruturas } \\
\text { descritivas } \\
\text { de atributo } \\
\text { semanticamente } \\
\text { transitório }\end{array}$ & $\begin{array}{l}\text { Variação entre } \\
\text { formas com e } \\
\text { sem inflexão } \\
\text { vocálica: } \\
\text { teftemonho } ~ \\
\text { teftemunho; } \\
\text { douida } \sim \text { duuida } \\
\text { Variação } \\
\text { entre formas } \\
\text { etimológicas e } \\
\text { analógicas, do } \\
\text { tipo fruyto } ~ \\
\text { froyto } \\
\text { Hiatos vocálicos } \\
\text { resultantes da } \\
\text { síncope de -N- na } \\
\text { terminação -ENA } \\
\text { (pea pẽa) } \\
\text { Ditongo oi no } \\
\text { item lexical } \\
\text { coirela } \\
\text { Formas } \\
\text { proclíticas dos } \\
\text { possessivos } \\
\text { femininos mha/ } \\
\text { mÆa/fa(s) }\end{array}$ & 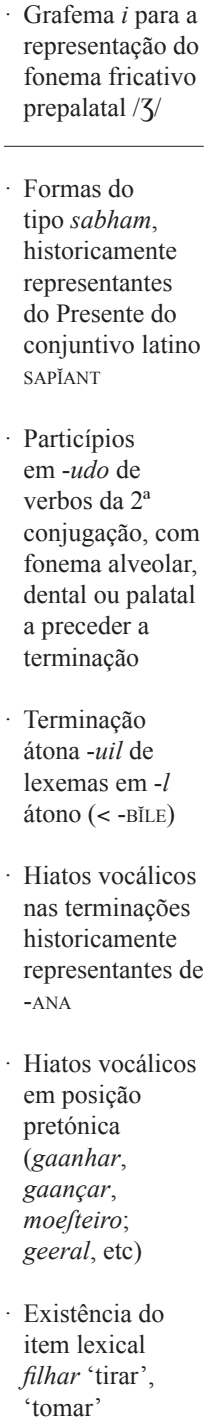 & $\begin{array}{l}\cdot \text { Variação entre } \\
\text { foy } \sim \text { fuy }\left(1^{\mathrm{a}}\right. \\
\text { pessoa do } \\
\text { singular de ESSE) } \\
\text { Formas verbais } \\
\text { do tipo conhocer } \\
\text { e derivados (com } \\
\text { o etimológico) } \\
\text { Formas de } \\
\text { infinitivo com } \\
\text { radical trag- } \\
\text { - Variação sufixal } \\
\text {-mento -ção; } \\
\text {-ia -mento } \\
\text { (obrigamento } ~ \\
\text { obrigação, } \\
\text { melhoria } ~ \\
\text { melhoramento), } \\
\text { em proveito dos } \\
\text { últimos produtos } \\
\text { lexicais, a partir } \\
\text { desta altura }\end{array}$ & 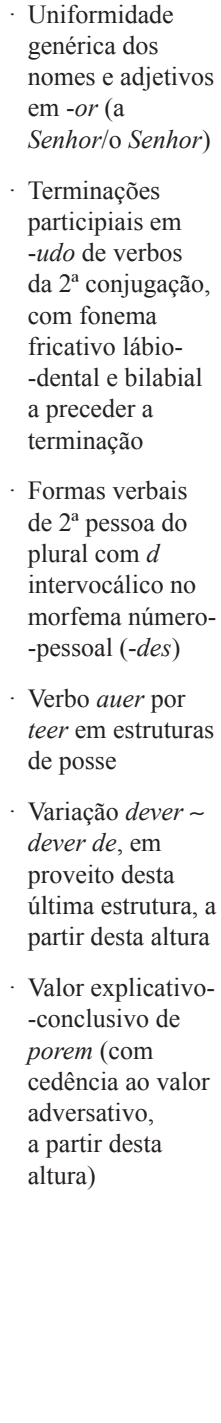 \\
\hline
\end{tabular}


O corpus deixa, todavia, adivinhar, como provámos já ao longo de variados trabalhos, outras múltiplas metamorfoses por que passou o português moderno e contemporâneo. Alguns deles têm a sua origem na segunda metade do século XV e, na nossa opinião, deverão difundir-se pelos séculos XVI, XVII e XVIII. Neles se incluem, por exemplo, a variação ou oi (pelo menos em alguns itens lexicais, nomeadamente nos que resultaram de processos de derivação), teer como auxiliar de tempo composto, teer em orações existenciais e estruturas "situativas" («onde nom tinha oficyaes», 1460 MA 113; «como na çedolla tem declarado», 1536 SC 150), semelhantes às da variedade brasileira, ausência de complementadores preposicionais de verbos como dever, inúmeros fenómenos de derivação, mudanças onomasiológicas, gramaticalização de conjunções e surgimento dos conectores modernos, entre muitos outros.

Gostaríamos, por fim, de finalizar este artigo com as mesmas palavras com que a saudosa Professora Rosa Virgínia Mattos e Silva encerra a sua "Introdução" ao volume I de O Português Arcaico. Uma aproximação:

Espero que, ao finalizar (...), tenha tido a possibilidade de levantar questões e transmitir sugestões para que se prossiga na tarefa complexa, mas parece que necessária, pelo menos por uma razão de ordem prática, uma vez que pode direcionar o historiador da língua a reflectir e propor segmentações no contínuo tornar-se da língua portuguesa (Silva 2008: 24).

\section{Bibliografia}

Ali, Manuel Said (1966). Gramática Histórica da Lingua Portuguêsa. 6. ${ }^{\text {a }}$ edição melhorada e aumentada de Lexeologia e Formação de Palavras e Sintaxe do Português Histórico. Estabelecimento do texto, revisão, notas e índices pelo Prof. Maximiano de Carvalho e Silva. S. Paulo: Edições Melhoramentos.

Bechara, Evanildo (1991). "As fases da língua portuguesa escrita”. Em Actes du XVIII Congrès International de Linguistique et de Philologie Romanes, vol. III, 68-76. Tübingen: Max Niemeyer Verlag.

Brocardo, Maria Teresa (2014). Tópicos de história da língua portuguesa. Lisboa: Colibri.

Cardeira, Esperança (2005). Entre o Português Antigo e o Português Clássico. Lisboa: Imprensa Nacional - Casa da Moeda.

Cardeira, Esperança (2015). “A fronteira entre o português antigo e clássico: português médio”. Em Mariño Paz, Ramón e Xavier Varela Barreiro (eds.), Lingüística 
histórica e edición de textos galegos medievais (= Verba, anexo 73, sem indicação de páginas). Universidade de Santiago de Compostela: Servizo de Publicacións e Intercambio Científico. http://repositorio.ul.pt/bitstream/10451/33237/1/VerbaEsperan\%c3\%a7a\%20Cardeira.pdf.

Carvalho (1996). Do Português arcaico ao Português moderno. Contributos para uma nova proposta de periodização. Dissertação de Mestrado em Linguística Portuguesa elaborada no âmbito do Programa "Praxis XXI" e apresentada à Faculdade de Letras de Coimbra. Coimbra: Faculdade de Letras (= Cota 55158 V da Biblioteca Nacional de Lisboa).

Carvalho (1999). "A alomorfia no plural dos nomes e adjetivos de lexema em -l: um estudo de morfologia histórica portuguesa". Em Lopes, Ana Cristina Macário e Cristina Martins (Orgs.), Actas do XIV Encontro Nacional da Associação Portuguesa de Linguística (Aveiro 1998), vol. I, 265-281. Braga: Associação Portuguesa de Linguística.

Carvalho (1999-2000). "Cronologia(s) da substituição da terminação participial -udo por -ido no português medieval (sécs. XIII-XVI)”, Revista Portuguesa de Filologia, 23, 381-409.

Carvalho (2000). "O morfema -des na história da língua portuguesa: uma abordagem segundo a metodologia da Sociolinguística histórica”. Em Annick Englebert, Michel Pierrard, Laurence Rosier et Dan Van Raemdonck (eds.), Actes du XXII Congrès International de Linguistique et de Philologie Romanes (Bruxelles, 23-29 juillet 1998), vol. II, 65-74. Tübingen: Max Niemeyer Verlag.

Carvalho (2002). "Periodização da língua portuguesa num contexto social: uma contribuição para a Sociolinguística histórica". Revista Galega de Filoloxía 3, 11-27. https://ruc.udc.es/dspace/bitstream/handle/2183/2593/RGF-3-1-def.pdf;jsessionid $=$ F2F97D2B5A13042D042FD01BAD334D9B sequence $=1$ (Consultado em 30 de novembro de 2019).

Carvalho (2005). "On the origin of the final unstressed [i] in Brazilian and other varieties of Portuguese: New evidence in an enduring debate". Em Michael Fortescue, Eva Skafte Jensen, Jens Erik Mogensen, Lene Schøsler (ed.), Historical Linguistics 2003. Selected Papers from the 16th International Conference on Historical Linguistics, Copenhagen, 11-15 August 2003 (CILT 257), 47-60.

Carvalho (2006). Documentação medieval do mosteiro de Santa Maria de Alcobaça (sécs. XIII-XVI). Edição e estudo linguístico. Dissertação de Doutoramento em Linguística Portuguesa, apresentada à Faculdade de Letras da Universidade de Coimbra [parcialmente inédita].

Carvalho (2010a). "A variação ser/estar num corpus alcobacense medieval”. Diacrítica. Série Ciências da Linguagem, 24/1, 349-372. https://repositorium.sdum.uminho. pt/bitstream/1822/23229/1/Diacritica24-1.pdf (Consultado em 30 de novembro de 2019). 
Carvalho (2010b). "Complementadores preposicionais na história da língua portuguesa: variação, gramaticalização e desgramaticalização", em Revista da Pesquisa \& PósGraduação da Universidade Federal de Ouro Preto, 10 (1), 101-111.

Carvalho (2010c). "Sintaxe e pragmática dos clíticos no português medieval". Matraga 26. Estudos Linguísticos e Literários. Revista do Programa de Pós-Graduação em Letras da UERJ, 17 (26), 113-131. https://www.e-publicacoes.uerj.br/index.php/ matraga/article/view/26327/18798 (Consultado a 30 de novembro de 2019).

Carvalho (2010-2011). “A gramaticalização e a lexicalização como processos históricos”. Estudos Linguísticos/Linguistic Studies, 6/7, 159-176. https://clunl.fcsh.unl.pt/wpcontent/uploads/sites/12/2018/02/159_176.pdf (Consultado a 30 de novembro de 2019).

Carvalho (2011a). "Duas inovações consonânticas num corpus medieval: simplificação do sistema de quatro sibilantes e neutralização da oposição fonológica $b / v$ ". Em Armanda Costa, Isabel Falé e Pilar Barbosa (eds.), XXVI Encontro Nacional da Associação Portuguesa de Linguística. Textos selecionados (Porto 2010). Lisboa: Associação Portuguesa de Linguística, 140-152. https://docplayer.com.br/347379Duas-inovacoes-consonanticas-num-corpus-medieval-simplificacao-do-sistema-dequatro-sibilantes-1-e-neutralizacao-da-oposicao-fonologica-b-v.html (Consultado a 30 de novembro de 2019).

Carvalho (2011b). "From etimology to cognitive sociolinguistics. A case-study from European Portuguese". Em Augusto Soares da Silva, Amadeu Torres e Miguel Gonçalves (orgs.), Línguas Pluricêntricas. Variação Linguística e Dimensões Sociocognitivas/ Pluricentric Languages. Linguistic Variation and Sociocognitive Dimensions, 353-364. Braga: Publicações da Faculdade de Filosofia/Universidade Católica Portuguesa.

Carvalho (2012). "Notas para uma análise semântica e pragmática do texto notarial medieval". Em Armanda Costa \& Inês Duarte (coord.), Nada na linguagem lhe é estranho. Homenagem a Isabel Hub Faria, 593-604. Santa Maria da Feira: Edições Afrontamento.

Carvalho (2013a). "Cognition, Grammaticalization and Syntactic Change. The emergence of Compound Tenses in Portuguese". Entrepalavras. Revista de Linguística do Departamento de Letras Vernáculas da Universidade Federal do Ceará 3, 2, 33-57. http://www.entrepalavras.ufc.br/revista/index.php/Revista/article/view/264/213 (Consultado a 30 de novembro de 2019).

Carvalho (2013b). "Contributo para o estudo da evolução das terminações nasais portuguesas (sécs. XIII-XVI)". Em Calvo Rigual, Cesáreo \& Casanova, Emili (eds.), Actes del 26é Congrès de Linguistica i Filologia Romàniques (valència, 6-11 de setembre de 2010), vol. 1, 567-577. Berlin/Boston: De Gruyter. https://ialnet. unirioja.es/servlet/libro?codigo=558191\#volumen124718 (Consultado a 30 de novembro de 2019). 
Carvalho (2014a). "Aspetos sociocognitivos da variação e da mudança semântica: Haver e Ter em estruturas de posse”, Diacritica. Série Ciências da Linguagem 28, 1: 347-375. http://cehum.ilch.uminho.pt/cehum/static/publications/diacritica_28-1.pdf (Consultado a 30 de novembro de 2019).

Carvalho (2014b). "Norma e desvio em estruturas com clíticos no Português do Brasil: evolução de ontem, interferências de hoje". Soletras. Revista do Departamento de Letras da Faculdade de Formação de Professores da Universidade do Estado do Rio de Janeiro 28, 2: 262-281. https://www.e-publicacoes.uerj.br/index.php/soletras/ article/view/12906/12494 (Consultado a 30 de novembro de 2019).

Carvalho (2015a). "Linguagem e Justiça: polissemia, «desambiguidade» e produtividade sufixal nos textos jurídicos, ao longo dos tempos", Biblos. Revista da Faculdade de Letras da Universidade de Coimbra (1. O Valor das Humanidades) 1, 1: 367-394. https://digitalis-dsp.uc.pt/bitstream/10316.2/37840/1/Linguagem\%20e\%20justica. pdf (Consultado a 30 de novembro de 2019).

Carvalho (2015b). "Para a história do infinitivo flexionado português: uma abordagem semântico-pragmática”. Zeitshrift für romanische Philologie (ZrP) 131, 3: 664-689. DOI: https://doi.org/10.1515/zrp-2015-0047.

Carvalho (2015c). "Sobre as origens de [u] átono no Português europeu contemporâneo: variação, mudança e dimensões sociocognitivas". Diacrítica. Série Ciências da Linguagem 29, 1: 171-202. http://cehum.ilch.uminho.pt/cehum/static/publications/ diacritica_29-1.pdf (Consultado a 30 de novembro de 2019).

Carvalho (2015d). "Sobre as origens dos valores de /e/ átono em posição medial no Português europeu e brasileiro". Revista Galega de Filoloxía, 16: 43-73. DOI: https://doi.org/10.17979/rgf.2015.16.0.1378.

Carvalho (2016a). "Dialetologia e história da língua: sobre a génese e condicionamento de alguns traços das atuais variedades do Português". Revista da Associação Portuguesa de Linguística 1, 1: 79-94. http://ojs.letras.up.pt/index.php/APL/login (Consultado a 30 de novembro de 2019).

Carvalho (2016b). "Prefixes in the history of Portuguese. A semantic and cognitive approach". Estudos de Lingüistica Galega, 8: 45-67. http://www.usc.es/revistas/ index.php/elg/article/view/2608/3643 (Consultado a 30 de novembro de 2019).

Carvalho (2016c). "Síncope de -N- e -L intervocálicos no (galego)-português medieval: resultados e cronologias". Verba. Anuario Galego de Filoloxía, 43: 1-46. http:// www.usc.es/revistas/index.php/verba/article/view/2074/3822 (Consultado a 30 de novembro de 2019).

Carvalho (2017a). Documentação medieval do mosteiro de Santa Maria de Alcobaça. Edição, com introdução e notas de aparato crítico (=Verba, Anexo 74). Universidade de Santiago de Compostela: Servicio de Publicacións e Intercambio Científico. DOI: https://doi.org/10.15304/9788416533817. 
Carvalho (2017b). "Fatores semânticos e pragmáticos na "desgramaticalização": a substituição do "Condicional" pelo Imperfeito no português". Filologia e Linguística Portuguesa, 19 (jan-jun 2017), 89-111. https://www. 2017revistas.usp.br/flp/article/ view/115016/136315 (Consultado em 30 de novembro de 2019).

Carvalho (2017c). "Novos caminhos na morfologia lexical do Português: perspetiva histórica”. Em Álvarez de la Granja, Maria, Boullón Agrelo, Ana Isabel \& González Seoane, Ernesto X. (eds.), Aproximacións á variación lexical en espaço galego-portugués. (= Revista Galega de Filoloxía, Monografía 11), A Coruña: Universidade da Coruña, 89-114. http://illa.udc.es/rgf/pdf/mon_11.pdf (Consultado em 30 de novembro de 2019).

Carvalho (2018a). "Ditongos orais e seus processos evolutivos na história do português". Estudos de Lingüistica Galega 10, 41-54. http://www.usc.es/revistas/index.php/elg/ article/view/4538/5652 (Consultado em 30 de novembro de 2019.

Carvalho (2018b). "Entre consoantes: grafemas e fonemas no scriptorium do mosteiro de Santa Maria de Alcobaça (sécs. XIII-XVI)". Revista Galega de Filoloxía 19, 41-72. http://revistas.udc.es/index.php/rgf/article/view/rgf.2018.19.0.4946/ g4946_pdf(Consultado em 30 de novembro de 2019).

Carvalho (2018c). "Na ausência de «ortografia»: representação grafemática dos sons vocálicos no scriptorium alcobacense". Em Pinto, Ana Paula, Maria José Lopes, António Melo, João Carlos Onofre Pinto, Álvaro Balsas (eds.), Verba Volant? Oralidade, Escrita e Memória, 159-182. Braga: Axioma - Publicações da Faculdade de Filosofia.

Carvalho, Maria José (2019). “Considerações sobre a cronologia de algumas mudanças na morfologia verbal do (galego)-português". Estudos de Lingüistica Galega 11, 233-264. http://www.usc.es/revistas/index.php/elg/article/view/5392/6776 (Consultado em 30 de novembro de 2019).

Castro, Ivo (com a colaboração de Rita Marquilhas e José Léon Acosta) (1991). Curso de história da língua portuguesa. Lisboa: Universidade Aberta.

Castro, Ivo (1993). "A elaboração da língua portuguesa, no tempo do Infante D. Pedro". Em Actas do Congresso Comemorativo do $6^{\circ}$ Centenário do Infante D. Pedro (25 a 27 de Novembro de 1992) (= Biblos. Revista da Faculdade de Letras, 69), 97-106.

Castro, Ivo (1999). "O Português médio segundo Cintra”. Em Isabel Hub Faria (org.), Lindley Cintra. Homenagem ao Homem, ao Mestre e ao Cidadão, 367-370. Lisboa: Edições Cosmos/Faculdade de Letras da Universidade de Lisboa.

Castro, Ivo (2006). Introdução à História do Português. Segunda edição revista e muito ampliada. Lisboa: Edições Colibri.

Charaudeau, Patrick (1992). Grammaire du sens et de l'expression. Paris: Hachette. 
Eberenz, Rolf (1991). "Castellano "antiguo" y español "moderno": reflexiones sobre la periodización en la historia de la lengua". Revista de Filología Española, vol. LXXI/1-2. http://xn--revistadefilologiaespaola-uoc.revistas.csic.es/index.php/rfe/ article/view/652/730 (Consultado em 30 de novembro de 2019).

Godinho, Vitorino Magalhães (1968). Ensaios, II. Sobre História de Portugal. Lisboa: Sá da Costa.

Gouveia, Carmen \& Carvalho, Maria José (2019, no prelo). "Processos de mudança na categoría gramatical de género em Português: dados de "corpora" medievais". Em Seara, Isabel Roboredo, Sebastião, Isabel \& Marques, Isabelle Simões (eds.), Discurso(s) de cumplicidade(s). Homenagem a Fernanda Menéndez. Lisboa/V.N. Famalicão: CLUNL-FCSH/Edições Húmus.

Maia, Clarinda de Azevedo (1994). "O Tratado de Tordesilhas. Algumas observações sobre o estado da língua portuguesa em finais do século XV”, Biblos. Revista da Faculdade de Letras, 70, 33-91.

Maia, Clarinda de Azevedo (1997²). História do galego-português. Estado linguístico da Galiza e do Noroeste de Portugal desde o século XIII ao século XVI (Com referência à situação do galego moderno). Reimpressão da edição de 1986. Lisboa: FCG e JNICT. (3. ${ }^{\text {a }}$ edição: https://digitalis.uc.pt/pt/livro/hist\%C3\%B3ria_do_galego_ portugu\%C3\%AAs_estado_lingu\%C3\%ADstico_da_galiza_e_do_noroeste_de_ portugal_desde_o).

Martins, Ana Maria (2002). "Mudança Sintáctica e História da Língua Portuguesa”, em Brian F. Head, José Teixeira, Aida Sampaio Lemos, Anabela Leal de Barros e António Pereira (Orgs.), História da Língua e História da Gramática. Actas do Encontro, 251-297. Braga: Universidade do Minho / Centro de Estudos Humanísticos.

Mattoso, José (dir.) (1993). História de Portugal, vol. II. Lisboa: Círculo de Leitores.

Messner, Dieter (1983). A peste de 1348, um factor muito pouco considerado nas histórias das línguas românicas. In: Boletim de Filologia, 28, 237-239.

Messner, Dieter (1994). Portugiesisch: Periodisierung. Périodisation. In: Lexikon der Romanistischen Linguistik, vol. VI, 2 (Gallego, Português), 618-623. Tübingen: Max Niemeyer Verlag.

Neto, Serafim da Silva $\left(1986^{4}\right)$. História da Língua Portuguesa. Rio de Janeiro: Presença (Em convénio com o Instituto Nacional do Livro/Fundação Nacional Pró-Memória).

Silva, Rosa Virgínia Mattos e (1994). "Para uma caracterização do período arcaico do português", Revista de Documentação de Estudos em Linguística Teórica e Aplicada (D.E.L.T.A), 10, número especial, 247-276.

Silva, Rosa Virgínia Mattos e (2008). O Português arcaico. Uma aproximação. Volume I: Léxico e morfologia. Lisboa: Imprensa Nacional - Casa da Moeda. 
Vasconcelos, Carolina Michaëlis (1956). Lições de Filologia Portuguesa (segundo as prelecções feitas aos Cursos de 1911/12 e de 1912/13), seguidas das «Lições práticas de Português arcaico». Nova edição da Revista de Portugal série A - Língua Portuguesa. Lisboa: Tipografia da Neogravura Lda,

Vasconcellos, José Leite (1926). Lições de Filologia Portuguesa. $2^{\text {a }}$ edição melhorada. Lisboa: Oficinas Gráficas da Biblioteca Nacional.

Vázquez Cuesta, Pilar e M. A. Mendes da Luz (1971). Gramática Portuguesa. Tercera edición corregida y aumentada. Madrid: Editorial Gredos. 